ISSN 1392-3196 / e-ISSN 2335-8947

Zemdirbyste-Agriculture, vol. 104, No. 1 (2017), p. 31-40

DOI 10.13080/z-a.2017.104.005

\title{
Molecular and phenotypic characterisation of diverse temperate maize inbred lines in Southeast Europe
}

\author{
Sanja MIKIĆ ${ }^{1}$, Ankica KONDIĆ-ŠPIKA ${ }^{1}$, Ljiljana BRBAKLIĆ ${ }^{2}$, Dušan STANISAVLJEVIĆ ${ }^{1}$, \\ Marina ĆERAN ${ }^{1}$, Dragana TRKULJA ${ }^{1}$, Bojan MITROVIĆ \\ 'Institute of Field and Vegetable Crops \\ Maksima Gorkog 30, 21000 Novi Sad, Serbia \\ E-mail: sanja.mikic@ifvens.ns.ac.rs
}

${ }^{2}$ Biogranum Research and Development Center

Toplice Milana 6, 21000 Novi Sad, Serbia

\begin{abstract}
Maize (Zea mays L.) displays large genetic diversity created during the history of introduction from its Mexican centre of origin to other parts of the world and adaptation to a range of diverse environments. Despite such diversity, maize breeders use only a small portion of the available maize germplasm to develop modern hybrids. Broadening diversity of breeding collections by the introduction of new germplasm, as a source of favourable traits, requires its characterisation and classification of new germplasm into heterotic groups. The aim of this study was to estimate genetic diversity of maize breeding material from the Institute of Field and Vegetable Crops in Serbia, including previously uncharacterised inbred lines, elite lines with known pedigrees and historically important inbred lines. Microsatellite-based cluster analysis and principal coordinate analysis separated 96 inbred lines into six clusters, Iowa Stiff Stalk Synthetic (BSSS), Lancaster Sure Crop (LSC), Iodent (IDT) heterotic group, a cluster with unrelated independent inbreds and two clusters of miscellaneous germplasm crossed with inbreds of BSSS and Lancaster background. The microsatellites umc1035, bnlg666, dupssr23, umc1083 and dupssr10 contributed most to the differentiation between the groups. The largest values of molecular diversity parameters were detected in the BSSS group, following by the Lancaster and then the other groups. An analysis of variance showed that almost all traits significantly varied among the groups and between the years. The investigated lines demonstrated sufficient variation in most of the analysed phenotypic traits, proving suitable for further genetic studies. A principal component analysis based on agronomic traits differentiated inbred lines from the BSSS and Lancaster pools, but failed to separate the other groups. The characterisation and classification of genetic resources using microsatellite markers may assist hybrid breeding by efficient exploitation of heterotic patterns.
\end{abstract}

Key words: heterotic groups, inbreds, microsatellites, simple sequence repeats, Zea mays.

\section{Introduction}

Maize (Zea mays L.), one of the most important cereal crops grown for food and feed globally, exhibits a large phenotypic and genotypic variability (Yan et al., 2009). A great diversity of agroecological environments for growing maize contributed to the development of divergent populations adapted to different edaphic and climatic conditions and biological factors, which ultimately manifested in a wide range of morphological, physiological, biochemical, agronomic and genetic traits.

Serbia belongs to the European Corn Belt, the world's second largestmaize growing area. Its southeastern and central parts, encompassed by the Pannonian Basin and spread throughout Hungary, southwestern Slovakia, Slavonia, northern Serbia and western Romania, present one of the main maize production regions in Europe (Stojaković et al., 2015). In these specific agroecological conditions, during the introductions of Caribbean,
Mexican, Andean, North American flints and American Corn Belt dents and following their successive crosses and adaptation, local maize varieties with distinct genetic backgrounds have been developed (Hadi, 2006). These diverse open-pollinated populations, adapted to various stress factors, such as drought, pathogen infections and pest infestations, and with high yield potential, were a valuable source of beneficial agronomic traits and used as initial breeding material in the 1960s in Southeast Europe (Mitrović et al., 2016). However, since the mid-twentieth century, the local germplasm began to gradually lose significance in regional breeding programmes, because of the global success of commercial maize hybrids. Nowadays, the narrow genetic base of modern hybrids is the main concern of maize breeders: only as few as six or seven inbred lines were identified to be founders of modern maize hybrids (Technow et al., 2014). 
The introduction of new germplasm into the existing breeding programmes is an essential step for broadening genetic diversity of working breeding material and could serve as an untapped source of favourable alleles. Maize breeders could enrich their working collections by introgressing a portion of local landraces, inbred lines developed from them, introduced accessions from gene banks and adapted exotic germplasm into elite inbred lines or into multiparental populations. Yet, such genetic material often has incomplete pedigree information and unknown heterotic response (El-Kassaby et al., 2011). To fully exploit the potential of such breeding material and phenomenon of heterosis, it is important to characterise it at molecular and phenotypic levels and assign newly developed inbred lines to heterotic groups. Traditionally, crosses are made between inbred lines with unknown heterotic response and inbred lines of different known heterotic groups and their $F_{1}$ offspring is observed for hybrid vigour, requiring at least two seasons and considerable land and labour resources.

Molecular markers, such as the most commonly used biallelic single nucleotide polymorphism (SNP) and multialelic simple sequence repeat (SSR), may facilitate characterisation and assignment of maize inbred lines to heterotic groups. The growing number of SNP-based maize genetic diversity studies due to decreasing costs per data point, high throughput application and large abundance of SNPs in the maize genome, do not necessarily presume the absolute supremacy of SNPs over SSRs. A recent study demonstrated the suitability of 1065 SNP markers to group 450 diverse maize inbreds according to their pedigrees using different multivariate methods, but it also showed their failure to clearly distinguish between two main maize heterotic groups (Semagn et al., 2012). Comparing the discriminating power of SSR and SNP markers in assessing maize diversity, $\mathrm{Wu}$ et al. (2016) indicated that the better genome coverage of SNPs contributed to their better performance. However, the authors pointed out that more SNPs were needed to compensate for highly polymorphic SSRs. Similarly, Yang et al. (2011) suggested that the moderate density of SSR markers was more informative than SNPs for maize diversity analyses.
The aim of this study was to assess adequacy of SSRs to estimate genetic diversity of maize breeding material from the Institute of Field and Vegetable Crops in Serbia, as a representative of Southeast European environment, to assign maize inbreds to heterotic groups and to analyse and compare molecular and phenotypic data of previously uncharacterised inbred lines to those whose pedigrees and heterotic groups are well-known in order to make the best used of available maize germplasm for breeding purposes.

\section{Materials and methods}

A collection of 96 diverse maize inbred lines, developed at the Institute of Field and Vegetable Crops in NoviSad, Serbia, was selected formolecular and phenotypic characterisation. They comprised several historically relevant inbred lines and the majority of elite inbred lines from Iowa Stiff Stalk Synthetic (BSSS), Lancaster Sure Crop (LSC) and Iodent (IDT) heterotic groups, unrelated independent (IND) heterotic group, inbred lines with mixed origin, including adapted non-tropical exotic germplasm, and local Serbian maize varieties, with limited information about their full pedigrees.

For molecular characterisation, genomic DNA was extracted from the bulk of approximately 10 seedlings for each maize inbred line using the CTAB (cetyl trimethylammonium bromide) method. Forty fluorescently labelled SSRs (Table 1) were used for polymerase chain reactions (PCR). Total PCR mix consisted of $25 \mathrm{ng}$ of genomic DNA, $0.2 \mathrm{mM}$ dNTP, $1 \times$ Taq buffer with $\mathrm{KCl}, 2 \mathrm{mM} \mathrm{MgCl}_{2}$, $1 \mathrm{U}$ Taq polymerase and 0.5 pmol of each primer (Applied Biosystems, USA). The first step of PCR started with DNA denaturation at $94^{\circ} \mathrm{C}$ for $5 \mathrm{~min}$, followed by 38 cycles for $30 \mathrm{~s}$ at $94^{\circ} \mathrm{C}, 45 \mathrm{~s}$ at the primer specific annealing temperature (Table 1), $45 \mathrm{~s}$ at $72^{\circ} \mathrm{C}$ and one cycle of the final extension for $7 \mathrm{~min}$ at $72^{\circ} \mathrm{C}$, performed on Veriti Thermal Cycler (Applied Biosystems, USA). The $10 \mu \mathrm{L}$ reaction volume for fragment analysis contained $2 \mu \mathrm{L}$ mixtures of differently labelled PCR products, $0.2 \mu \mathrm{L}$ GeneScan500 LIZ size standard and 7.8 $\mu \mathrm{L} \mathrm{Hi-Di} \mathrm{formamide} \mathrm{(Applied}$

Table 1. Names, chromosome locations, primer sequences, annealing temperatures, expected allele size and repeat motifs of forty analysed microsatellite markers

\begin{tabular}{|c|c|c|c|c|c|}
\hline Locus & Bin & Forward and reverse primers & $\begin{array}{c}\text { Annealing } \\
\text { temperature } \\
{ }^{\circ} \mathrm{C}\end{array}$ & $\begin{array}{l}\text { Allele } \\
\text { range } \\
\text { bp }\end{array}$ & $\begin{array}{c}\text { Repeat } \\
\text { motif }\end{array}$ \\
\hline 1 & 2 & 3 & 4 & 5 & 6 \\
\hline bnlg1067 & 8.03 & $\begin{array}{l}\text { 5'-GGCTTGCTTTTGCTTCACTT-3' } \\
\text { 5'-CTCATCCCATTCGTTCCACT-3' }\end{array}$ & 63 & $116-130$ & AG(26) \\
\hline bnlg1209 & 9.04 & $\begin{array}{l}\text { 5'-GTCCCGGGCAGAATAATACC-3', } \\
\text { 5'-TTCCTCCTTGAAGTGCTCGT-3' }\end{array}$ & 53 & $164-196$ & $\mathrm{AG}(12)$ \\
\hline bnlg1237 & 5.05 & $\begin{array}{l}\text { 5'-TGGCGCGATTTTCTTCATAT-3' } \\
\text { 5'-AAAGAGCAACCTTCAACGGA-3' }\end{array}$ & 58 & $151-185$ & $\mathrm{AG}(29)$ \\
\hline bnlg125 & 2.02 & $\begin{array}{l}\text { 5'-GGGACAAAAGAAGAAGCAGAG-3' } \\
\text { 5'-GAAATGGGACAGAGACAGACAAT-3' }\end{array}$ & 53 & $164-196$ & unknown \\
\hline bnlg 1360 & 10.07 & $\begin{array}{l}\text { 5'-TCTGCTCATCCACAACTTGC-3' } \\
\text { 5'-AGAACGTGAAGCTGAGCGTT-3' }\end{array}$ & 58 & $105-139$ & $\mathrm{AG}(25)$ \\
\hline bnlg1451 & 10.02 & $\begin{array}{l}\text { 5'-TGATCGATGGCTCAATCAGT-3', } \\
\text { 5'-ATCTGGAACACCGTCGTCTC-3' }\end{array}$ & 58 & $164-190$ & AG(34) \\
\hline bnlg1520 & 2.09 & $\begin{array}{l}\text { 5'-TCCTCTTGCTCTCCATGTCC-3', } \\
\text { 5'-ACAGCTGCGTAGCTTCTTCC-3' }\end{array}$ & 53 & $165-195$ & $\mathrm{AG}(22)$ \\
\hline bnlg1523 & 3.03 & $\begin{array}{l}\text { 5'-GAGCACAGCTAGGCAAAAGG-3' } \\
\text { 5'-CTCGCACGCTCTCTCTTCTT-3' }\end{array}$ & 53 & $176-236$ & $\mathrm{AG}(17)$ \\
\hline
\end{tabular}


Table 1 continued

\begin{tabular}{|c|c|c|c|c|c|}
\hline 1 & 2 & 3 & 4 & 5 & 6 \\
\hline bnlg1525 & 9.07 & $\begin{array}{l}\text { 5'-AGGAATTGCGAGTCTTCCAA-3', } \\
\text { 5'-CAACCCCCAAAATGAACAAA-3' }\end{array}$ & 56 & $156-200$ & $\mathrm{AG}(25)$ \\
\hline bnlg1556 & 1.07 & $\begin{array}{l}\text { 5'-ACCGACCTAAGCTATGGGCT-3' } \\
\text { 5'-CCGGTTATAAACACAGCCGT-3' }\end{array}$ & 53 & $150-184$ & $\mathrm{AG}(18)$ \\
\hline$b n \lg 162$ & 8.05 & $\begin{array}{l}\text { 5'-ACTAGCAGCAGTAAAACCTAATAAAGGA-3' } \\
\text { 5'-CAAGTAGCTAGCAGTCATTTGCAGTGT-3' }\end{array}$ & 56 & $214-260$ & unknown \\
\hline bnlg1792 & 7.02 & $\begin{array}{l}\text { 5'-CGGGAATGAATAAGCCAAGA-3' } \\
\text { 5'-GCGCTCCTTCACCTTCTTTA-3' }\end{array}$ & 58 & $107-139$ & $\mathrm{AG}(16)$ \\
\hline bnlg2291 & 4.06 & $\begin{array}{l}\text { 5'-CCTCTCGATGTTCTGAAGCC-3', } \\
\text { 5'-GTCATAACCTTGCCTCCCAA-3' }\end{array}$ & 53 & $153-197$ & AG(17) \\
\hline bnlg238 & 6.00 & $\begin{array}{l}\text { 5'-CTTATTGCTTTCGTCATACACACACATCAT-3' } \\
\text { 5'-GAGCATGAGCTTGCATATTTCTTGTGG-3' }\end{array}$ & 58 & 135-179 & unknown \\
\hline bnlg430 & 9.03 & $\begin{array}{l}\text { 5'-CTTACTGAGCATCTTCCTTCTCTCC-3' } \\
\text { 5'-TCCGGTGATGCTCCAGCGAC-3' }\end{array}$ & 58 & $99-111$ & unknown \\
\hline bnlg666 & 8.05 & $\begin{array}{l}\text { 5'-AAAAGGCAAGTAGCTAGCATGCATTGCAG-3' } \\
\text { 5'-GGCTCACGTCCGTATCCAAACCAACA-3' }\end{array}$ & 58 & $111-158$ & unknown \\
\hline dupssr10 & 5.04 & $\begin{array}{l}\text { 5'-AGAAAATGGTGAGGCAGG-3' } \\
\text { 5'-TATGAAATCTGCATCTAGAAATTG-3' }\end{array}$ & 53 & 156-198 & $\mathrm{AC}(22)$ \\
\hline dupssr 23 & 3.06 & $\begin{array}{l}\text { 5'-TGATCATCATAAGCACACCG-3' } \\
\text { 5'-CCAATGTGAAGCAAGAGAGAA-3' }\end{array}$ & 56 & $64-118$ & (GA)2TA(GA) 19 \\
\hline dupssr26 & 1.04 & $\begin{array}{l}\text { 5'-GTCGGAGCACTCCAAGAC-3' } \\
\text { 5'-CTTCTCGCTCATCAGCTTAAA-3' }\end{array}$ & 53 & $112-142$ & (GA)23 \\
\hline$n c 005$ & 4.05 & $\begin{array}{l}\text { 5'-CCTCTACTCGCCAGTCGC-3', } \\
\text { 5'-TTTGGTCAGATTTGAGCACG-3' }\end{array}$ & 56 & $120-152$ & $\mathrm{CT}$ \\
\hline phi027 & 9.03 & $\begin{array}{l}\text { 5'-CACAGCACGTTGCGGATTTCTCT-3' } \\
\text { 5'-GCGTACGTACGACGAAGACAC-3' }\end{array}$ & 58 & $141-156$ & GCGCT \\
\hline phi034 & 7.02 & $\begin{array}{l}\text { 5'-TAGCGACAGGATGGCCTCTTCT-3' } \\
\text { 5'-GGGGAGCACGCCTTCGTTCT-3' }\end{array}$ & 58 & $118-149$ & $\mathrm{CCT}$ \\
\hline phi053 & 3.05 & $\begin{array}{l}\text { 5'-CTGCCTCTCAGATTCAGAGATTGAC-3' } \\
\text { 5'-AACCCAACGTACTCCGGCAG-3' }\end{array}$ & 53 & $150-190$ & ATAC \\
\hline phi059 & 10.02 & $\begin{array}{l}\text { 5'-AAGCTAATTAAGGCCGGTCATCCC-3' } \\
\text { 5'-TCCGTGTACTCGGCGGACTC-3' }\end{array}$ & 58 & $139-154$ & $\mathrm{ACC}$ \\
\hline phi083 & 2.04 & $\begin{array}{l}\text { 5'-CAAACATCAGCCAGAGACAAGGAC-3' } \\
\text { 5'-ATTCATCGACGCGTCACAGTCTACT-3' }\end{array}$ & 56 & $121-137$ & AGCT \\
\hline phi093 & 4.08 & $\begin{array}{l}\text { 5'-AGTGCGTCAGCTTCATCGCCTACAAG-3', } \\
\text { 5'-AGGCCATGCATGCTTGCAACATGGATACA-3' }\end{array}$ & 58 & $280-296$ & AGCT \\
\hline umc1014 & 6.04 & $\begin{array}{l}\text { 5'-GAAAGTCGATCGAGAGACCCTG-3' } \\
\text { 5'-CCCTCTCTTCACCCCTTCCTT-3' }\end{array}$ & 58 & $113-141$ & (GA)12 \\
\hline umc1022 & 4.01 & $\begin{array}{l}\text { 5'-AACAAGTTTTGTTTGACAAGCCG-3' } \\
\text { 5'-ATGATCACCCCGTCAGCG-3' }\end{array}$ & 53 & $65-97$ & $(\mathrm{CA}) 9$ \\
\hline umc1025 & 3.04 & $\begin{array}{l}\text { 5'-GCTCCACTTCCACCCTGATATG-3' } \\
\text { 5'-CGCTAATGTCCCCATTGATGAT-3' }\end{array}$ & 56 & $101-117$ & (CT) 11 \\
\hline umc1035 & 1.06 & $\begin{array}{l}\text { 5'-CTGGCATGATCACGCTATGTATG-3', } \\
\text { 5'-TAACATCAGCAGGTTTGCTCATTC-3' }\end{array}$ & 58 & $110-212$ & (CT)19 \\
\hline umc1075 & 8.01 & $\begin{array}{l}\text { 5'-GAGAGATGACAGACACATCCTTGG-3' } \\
\text { 5'-ACATTTATGATACCGGGAGTTGGA-3' }\end{array}$ & 56 & $136-146$ & $(\mathrm{ATTGC}) 5$ \\
\hline umc1083 & 6.02 & $\begin{array}{l}\text { 5'-CTTTCCTCTCTGGAGCGTGTATTG-3', } \\
\text { 5'-ATATGTTGCAGAACCATCCAGGTC-3' }\end{array}$ & 56 & $90-128$ & (GA)16 \\
\hline umc1109 & 4.01 & $\begin{array}{l}\text { 5'-GCAACACAGGACCAAATCATCTCT-3', } \\
\text { 5'-GTTCGGTCCGTAGAAGAACTCTCA-3' }\end{array}$ & 56 & $103-115$ & $(\mathrm{ACG}) 4$ \\
\hline umc1122 & 1.06 & $\begin{array}{l}\text { 5'-CACAACTCCATCAGAGGACAGAGA-3' } \\
\text { 5'-CTGCTACGACATACGCAAGGC-3' }\end{array}$ & 58 & $141-168$ & $(\mathrm{CGT}) 7$ \\
\hline umc1221 & 5.04 & $\begin{array}{l}\text { 5'-GCAACAGCAACTGGCAACAG-3', } \\
\text { 5'-AAACAGGCACAAAGCATGGATAG-3' }\end{array}$ & 56 & 69-95 & $(\mathrm{CT}) 7$ \\
\hline umc1360 & 8.02 & $\begin{array}{l}\text { 5'-GCTAGTTGAGTTCGACACCAGGTT-3', } \\
\text { 5'-TGACTGTGACTGTGACTATGACCG-3' }\end{array}$ & 56 & $139-160$ & $(\mathrm{ACA}) 4$ \\
\hline umc1792 & 5.08 & $\begin{array}{l}\text { 5'-CATGGGACAGCAAGAGACACAG-3', } \\
\text { 5'-ACCTTCATCACCTGCAACTACGAC-3' }\end{array}$ & 58 & $113-128$ & (CGG)5 \\
\hline umc1944 & 7.04 & $\begin{array}{l}\text { 5'-GAAGAAGGATCGCACACATGG-3', } \\
\text { 5'-AGACTGTCGCGCTGTACTATACCC-3' }\end{array}$ & 56 & $117-145$ & unknown \\
\hline umc 2003 & 10.04 & $\begin{array}{l}\text { 5'-CTCATCGGTTAGCAGCAGCAG-3', } \\
\text { 5'-GTTCTTAATCGGCACTCCTCGTC-3' }\end{array}$ & 58 & $71-91$ & unknown \\
\hline umc 2176 & 4.03 & $\begin{array}{l}\text { 5'-ATAGATCTTTGTCGCGTGTTCTGC-3', } \\
\text { 5'-CTCAAGAACACCACCAGACGAGTT-3' }\end{array}$ & 58 & $130-154$ & (TGC)4 \\
\hline
\end{tabular}


Biosystems, USA). The PCR products were separated by capillary electrophoresis on ABI Prism 3130 and their sizes were determined and visualised with software Gene Mapper, version 4.0 (Applied Biosystems, USA).

To classify maize inbred lines based on the data of SSR markers, a cluster analysis was performed with unweighted pair-group method using arithmetic average algorithm (UPGMA) to reconstruct the phylogeny from a Roger's frequency-based distance in the software PowerMarker 3.25 (North Carolina State University, USA) and visualised in the software Dendroscope 3 (Huson et al., 2007). The molecular data was analysed in GenAlEx 6.5 (Peakall, Smouse, 2012) and presented with the following molecular diversity parameters: average number of different alleles, average number of different alleles excluding rare variant with minor allele frequency less than $5 \%$, average number of effective alleles $(1 /$ $\left.\left(\Sigma p_{i}^{2}\right)\right)$, Shannon's information index $\left(-1 \times \Sigma\left(p_{i} \times \ln \left(p_{i}\right)\right)\right)$, average number of alleles specific to each group, number of common alleles, observed heterozygosity and expected heterozygosity $\left(1-\Sigma p_{i}^{2}\right)$, where $p_{i}$ is the frequency of the $i^{\text {th }}$ allele and $\Sigma p_{i}^{2}$ is the sum of the squared allele frequencies (Peakall, Smouse, 2012). The analysis of molecular variance $(A M O V A)$ was applied to partition genetic variation among groups based on the codominant allelic distance matrix and fixation index (Fst) was calculated to measure the genetic differentiation among groups, as a proportion of the estimated variance among populations in the total variance. The principal coordinate analysis (PCoA) was used to visualise the patterns of genetic relationship among inbred lines via covariance matrix with data standardization in a trial version of software XLSTAT 2016.1 (Addinsoft, USA).

The phenotypic evaluation of inbred lines was performed for eight traits, namely, number of days to pollination, plant height $(\mathrm{cm})$, ear diameter $(\mathrm{cm})$, ear length $(\mathrm{cm})$, number of rows per ear, number of kernels per row, number of leaves per plant and grain yield per plant (g). The trial was conducted during 2011 and 2012 in a randomized complete block design with three replicates in two locations, Rimski šančevi $\left(45^{\circ} 20^{\prime} \mathrm{N}, 19^{\circ} 51^{\prime} \mathrm{E}\right.$, $84 \mathrm{~m}$ a.s.1.) and Srbobran $\left(19^{\circ} 09^{\prime} \mathrm{E}, 45^{\circ} 46^{\prime} \mathrm{N}, 88 \mathrm{~m}\right.$ a.s.1.). This area has a continental semi-arid climate and Chernozem soil type. The average precipitation in 2011 and 2012 was $488 \mathrm{~mm}$ and $388 \mathrm{~mm}$, respectively, while the average daily temperatures were $12^{\circ} \mathrm{C}$ and $12.8^{\circ} \mathrm{C}$, for 2011 and 2012, respectively. More meteorological and climatic data for the tested locations is available on the official site of the Hydrometeorological Service of the Republic of Serbia (http://www.hidmet.sr.gov.rs). Standard cultivation technology adapted to local agroecological conditions was applied. The application of the mineral fertilisers was based on the soil chemical analyses and the timing and method of their application were the same for the tested sites. The plot size for each genotype was $6 \mathrm{~m}^{2}$ and consisted of two rows, each $4 \mathrm{~m}$ long. The distance between rows was 0.75 and $0.22 \mathrm{~m}$ within rows, with a density of 60,600 plants ha-1.

An analysis of variance ( $A N O V A)$ for phenotypic traits and Tukey's multiple comparisons of means test for $95 \%$ and $99 \%$ confidence levels were performed to test differences between mean values. A multivariate data analysis method, principal component analysis (PCA), was used in a trial version XLSTAT 2016 (Addinsoft, USA) to visualise a pattern of relationship between inbred lines based on the phenotypic data.

\section{Results and discussion}

The cluster analysis performed with UPGMA algorithm based of Roger's distance from 40 microsatellites, distinguished inbred lines according to their affiliation to heterotic groups (Fig. 1). Out of the total 96 analysed inbred lines, 36 lines grouped in the BSSS cluster, including referent lines B14, B37, B73 and $\mathrm{B} 84$, developed in different cycles of recurrent selection from the BSSS population. The inbred lines B14 and B37 had the largest direct ancestral contributions to the BSSS heterotic group in the first pre-1950 era of maize breeding in North America, while B73 was the main contributor to this heterotic group in the second pre-1980 era (van Heerwaarden et al., 2012). Distinctive sub-clusters were formed within the BSSS cluster with each referent line as a representative of the sub-cluster. A separate cluster from the BSSS group, but close to it, was also differentiated. It was formed by inbred lines with predominant BSSS background mixed in different proportions with other germplasm, such as local, exotic and other genetic material of unknown origin. This cluster of mixed BSSS genetic constitution was denoted as mBSSS and

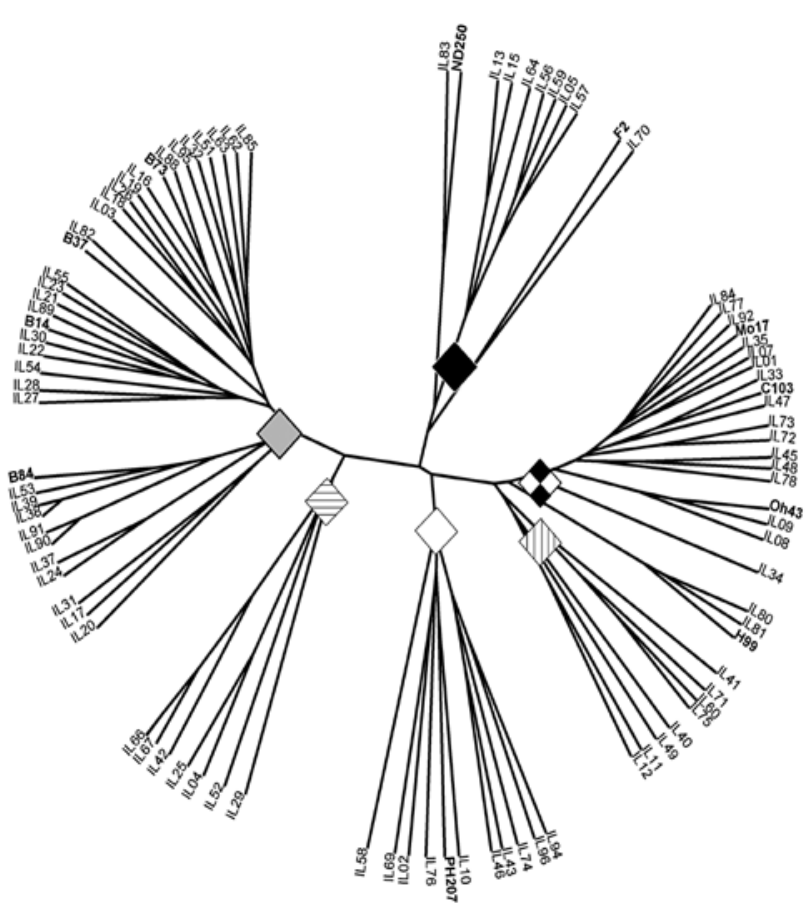

Note. Grey square presents maize inbred lines that belong to the Iowa Stiff Stalk Synthetic (BSSS) pool, horizontal lines square denotes BSSS inbred lines mixed with lines of other origins, black square marks inbred lines from various independent sources, white square represents Iodent (IDT) lines, vertical lines square denotes Lancaster Sure Crop (LSC) inbred lines mixed with lines from other groups and diamond square shows LSC inbred lines.

Figure 1. Radial dendrogram of 96 maize inbred lines based of Roger's allele frequency distance of 40 simple sequence repeat (SSR) markers 
represented in Figure 1 with a horizontal line square. Twenty three inbreds were assembled in the LSC pool, encompassing C103, Mo17, H99 and Oh43. Two related inbred lines, C103 and Mo17, were grouped in the same sub-cluster, as expected, since Mo17 was developed from the CI187.2 $\times$ C103 cross. The inbred Oh43 also formed a separate sub-cluster. This inbred has Richey Lancaster, Minnesota 13 and Northwestern Dent in its pedigree. The line H99, developed from Illinois Synthetic 60C with Richey Lancaster background, was distant from the other referent lines in this group. Similarly to mBSSS, a group of inbreds of LSC origin mixed with germplasm from local maize populations, IDT and other various independent genetic material, was separated from the LSC group and was denoted as mLSC. Eleven inbred lines of IDH origin grouped together in a single cluster, with PH207 as a representative. The inbreds Mo17 and PH207 were the main representatives of the second historical era of maize breeding with the highest contributions to the nonBSSS (or traditionally designated Lancaster) and Iodent genepools, respectively (var Heerwaarden et al., 2012). Eleven lines with independent heterotic response formed a cluster encompassing adapted exotic inbred lines of Argentinean origin, the lines containing local Serbian germplasm, European flints and other independent sources, with F2 and ND250 as references. The remaining inbred lines with a considerable portion of referent lines' genetic background in their pedigrees and some inbreds with undisclosed pedigrees were grouped by genetic similarity into the corresponding sub-clusters. Similar patterns of clustering, represented by the main referent historical inbred lines, were also identified in other studies. Wu et al. (2015) revealed clustering patterns of 1857 maize accessions from around the world represented by Mo17, B73, 207, Oh43 and A634 (containing 87.5\% of B14 germplasm), several Chinese lines, Reid Yellow Dent, tropical and subtropical germplasm. The B73, Mo17, Oh43, PH207 and A321 maize subpopulations were identified with SSR and SNP markers by Schaefer and Bernardo (2013). Pedigree information and shared allele frequencies of the inbred lines developed at the Institute of Field and Vegetable Crops, Serbia and the referent historical lines, such as B73, Mo17, B14 and PH207, showed a considerable contribution of these ancestor-inbreds to in the lineage of the modern inbred lines and indicated the importance in maize breeding in the southeast Europe.

An analysis of molecular variance showed that genetic variation was much higher within the groups $(93 \%)$, while variance among six groups was around $7 \%$ (Table 2). The genetic differentiation among the groups was significant, and pair-wise fixation index ranged from 0.024 between the LSC and the IDT subpopulations to 0.191 between the mBSSS and the IDT subpopulations. The average $F s t$ value was 0.069 , larger than in breeding programs of the Corn Belt (Romay et al., 2013), between

Table 2. Analysis of molecular variance among and between six groups of maize inbred lines

\begin{tabular}{cccccccc}
\hline Source & $\begin{array}{c}\text { Degrees of } \\
\text { freedom }\end{array}$ & $\begin{array}{c}\text { Sum of } \\
\text { squares }\end{array}$ & $\begin{array}{c}\text { Mean } \\
\text { square }\end{array}$ & $\begin{array}{c}\text { Estimated } \\
\text { variance }\end{array}$ & $\begin{array}{c}\text { Estimated variance } \\
\%\end{array}$ & $\begin{array}{c}F s t \\
\text { value }\end{array}$ & $\begin{array}{c}P \\
\text { value }\end{array}$ \\
\hline Among groups & 5 & 186.839 & 37.368 & 0.874 & 6.9 & 0.069 & 0.001 \\
Within groups & 186 & 2186.843 & 11.757 & 11.757 & 93.1 & & \\
Total & 191 & 2373.682 & & 12.631 & 100.0 & & \\
\hline
\end{tabular}

tropical and temperate lines (Liu et al., 2015) and between elite Chinese lines and public US lines (Jiao et al., 2012). However, obtained Fst value in this study was smaller compared to $F s t=0.165$ in a diverse panel of 284 maize inbreds (Schaefer, Bernardo, 2013).

Comparison of different parameters of genetic diversity among six maize groups, showed that the largest average number of alleles (6.78), number of rare alleles (4.58), effective number of alleles (3.77), Shannon's information index (1.45) and number of private alleles per locus (1.53) were detected in the BSSS group, followed by the LSC and then the other groups (Table 3). Moreover, the BSSS group had the fewest alleles shared with other groups (0.42); whereas LSC inbred lines had the largest average number of common alleles (1.33). Expected heterozygosity for all the analysed inbred lines was 0.68 , with the smallest values observed in the mLSC and the largest in the LSC group. The number of alleles and expected heterozygosity depended on the type and number of markers and the diversity of germplasm used. Microsatellites, comparing to other marker systems, excel at high discrimination power due to multiple alleles (Olmos et al., 2014). The genetic diversity assessed by SSRs in this study was similar or larger compared to other maize studies with the same marker type. Jones et al. (2007) found on average 5.1 alleles and expected heterozygosity of 0.62 among 58 inbred lines characterised by 80 SSRs. Much lower number of alleles

Table 3. Parameters of genetic diversity in maize heterotic groups obtained with microsatellites

\begin{tabular}{llllcccc}
\hline \multicolumn{1}{c}{ Allelic parameter/group } & ITD & IND & LSC & mLSC & BSSS & mBSSS & Total \\
\hline Average number of alleles & 3.81 & 3.47 & 4.89 & 3.25 & 6.78 & 3.11 & 8.25 \\
Average number of alleles with $\geq 5 \%$ & 3.47 & 3.39 & 3.80 & 3.05 & 4.58 & 3.11 & 5.93 \\
Number of effective alleles & 2.64 & 2.63 & 3.20 & 2.60 & 3.77 & 2.33 & 3.57 \\
Shannon's Information Index & 1.07 & 1.03 & 1.24 & 1.00 & 1.45 & 0.86 & 1.45 \\
Average number of private alleles & 0.08 & 0.11 & 0.56 & 0.27 & 1.53 & 0.22 & - \\
Average number of common alleles & 0.83 & 0.73 & 1.33 & 0.53 & 0.43 & 0.55 & - \\
Expected heterozygosity & 0.64 & 0.58 & 0.69 & 0.48 & 0.59 & 0.57 & 0.68 \\
\hline
\end{tabular}

IDT - Iodent, IND - independent, LSC - Lancaster Sure Crop, mLSC - mixed Lancaster Sure Crop, BSSS - Iowa Stiff Stalk Synthetic, mBSSS - mixed Iowa Stiff Stalk Synthetic 
per locus and expected heterozygosity of the LSC, the BSSS and other groups were observed in the study of Zheng et al. (2008), while the values of these genetic parameters in the study of Yang et al. (2011) were similar to our findings.

The microsatellite markers umc1035, bnlg666, dupssr23, umc1083 and dupssr10 most efficiently differentiated between the heterotic groups, as they had the largest number of private alleles (6 to 11). Additionally, these five markers had different alleles present in at least 4 heterotic groups, demonstrating their high discriminatory power. Within each group, the percent of private alleles was the highest for the BSSS (22.6\%) and LSC (11.5\%) pools. The highest values of genetic diversity parameter in BSSS and LSC are not surprising, since these are two most important heterotic groups and the genetic distance between them increased gradually during selection for yield (Cooper et al., 2009). The results also indicate the importance of the most diverse BSSS group in common BSSS-Lancaster and BSSS-Iodent heterotic patterns in breeding programmes, as well as the positive effects of previous introduction of new germplasm and reselection in existing inbred lines collections. The lower percentage of group-specific alleles in the other groups could be due to the smaller number of contributing inbred lines. Different number of lines in the groups reflects the actual participation of each group in a real breeding programme. The similar portions of private alleles in different groups and subgroups were found in the research of Yang et al. (2010). The microsatellites revealed considerable genetic diversity of investigated inbred lines, which may be used in diversity-based QTL analyses (Holland, 2007), as a source of mining of beneficial alleles for introgressing traits of interest or heterotic group partitioning of allelic combinations for planning crosses to exploit hybrid vigour (Guo et al., 2014; Olmos et al., 2014).

A principal coordinate analysis (PCoA) was performed to visualise relative genetic relationship between maize inbred lines and to determine if there was agreement in grouping inbreds using PCoA and UPGMA clustering method. The percentage of the total variation explained by the first two coordinates was $22.8 \%$ and $17.8 \%$, respectively (Fig. 2). The first coordinate separated the inbred lines that belonged to the BSSS heterotic group from the rest, while the second coordinate differentiated the LSC lines. The IDT inbreds were clearly distinguished from the BSSS and LSC groups. The IND lines clustered together coherently to some extent in the centre of the biplot, with certain overlaps with the IDT, mBSSS and mLSC lines. This is understandable as the most of the inbreds from this cluster are not related and have quite different genetic background, which was reflected in their positioning on the plot towards the adjacent groups. Likewise, some mBSSS and mLSC inbred lines inclined towards BSSS, LSC or the independent cluster, since a portion of these clusters play a certain role in their genetic makeup. Our results were in accordance with PCoA of 266 elite Texas lines based on SNP markers by Smith et al. (2015). The first principal coordinate in their study separated the BSSS from the rest, while the second coordinate differentiated other non-Stiff Stalks, Texas cluster, tropical lines and Iodent group.

The PCoA results showed a good agreement with the UPGMA analysis. Although UPGMA provided clearer perspective in distinguishing clusters and subclusters of inbred lines according to their pedigrees, PCoA allowed more insight into relationship between the lines, especially those of mixed origin. It is noteworthy to point out that mBSSS and mLSC groups, although denoted as separate clusters from BSSS and LSC, respectively, do not represent distinct heterotic groups. Moreover, they belong to the BSSS and LSC heterotic groups, as the largest part of their genetic background is constituted of those two heterotic pools. Their separation into distinct clusters served to analyse the effects of introduction of various germplasm into two most popular and widely used

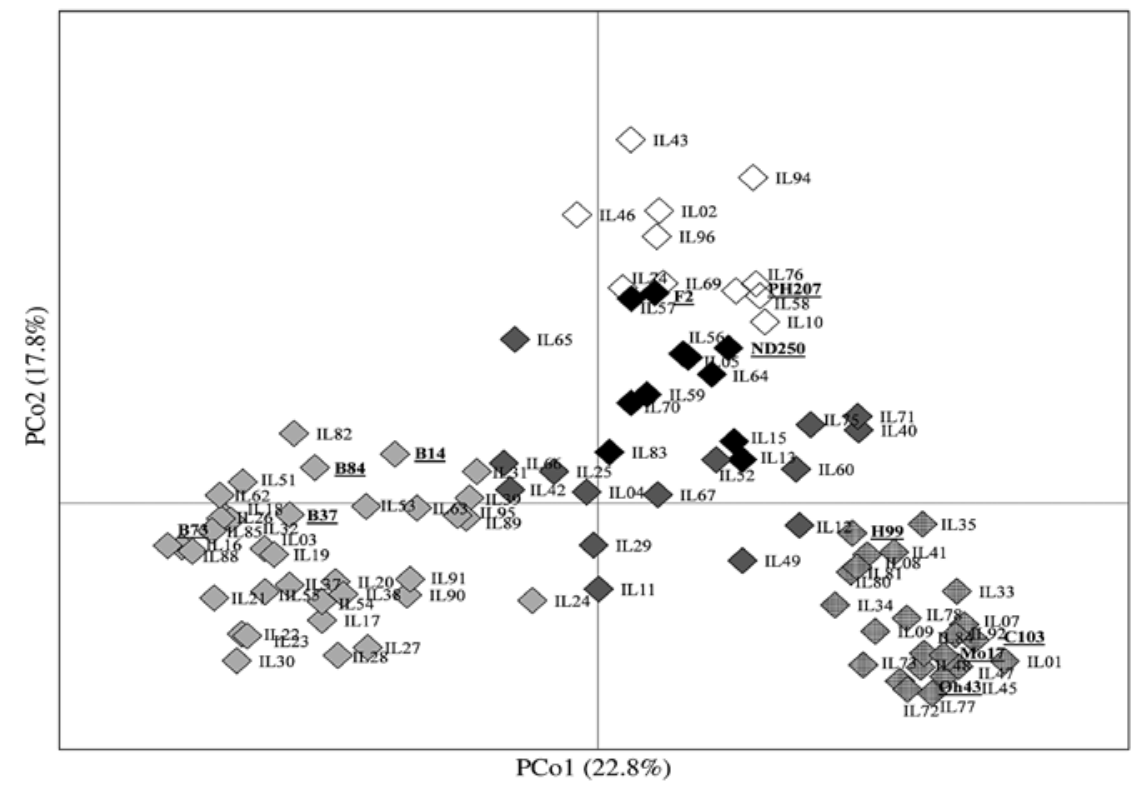

Note. Vertical lines - LSC inbred lines mixed with lines from other groups, horizontal lines - BSSS inbred lines mixed with those of other origins; grey - maize inbred lines belonging to BSSS pool, black - inbred lines from various independent sources, white - IDT lines, diamond - LSC inbred lines.

Figure 2. Principal coordinate analysis (PCoA) of 96 maize inbred lines based on microsatellite data 
heterotic groups in breeding programmes. Thus, our results demonstrated the efficiency of SSR markers to accurately classify inbreds in heterotic groups and subgroups and also support the argument that the differences among heterotic groups are more the outcome of modern breeding than the result of differentiation of genetically diverse founders (van Heerwaarden et al., 2012).

The analysis of variance of different phenotypic traits (days to pollination, plant height, number of leaves, ear length, ear diameter, number of rows per ear, number of kernels per ear row and grain yield) of the six groups of maize inbred lines is showed in Table 4. Almost all traits significantly varied among the groups and between the trial years. There were no significant differences in yield mean values between the maize groups. This is not surprising as the inbred lines included in the study have undergone the selection process for good performances, especially high yield per se for hybrid seed production. All the traits, except leaf number, significantly differed in two years of the experiment, while the location significantly affected variation of only two traits, namely, days to pollination and number of kernels per ear row. Significantly lower values of traits in 2012, as compared to 2011 , can be attributed to severe drought period during the flowering, fertilisation and grain filling stages. Most of the interactions between maize groups, years and locations were not significant, save those between years and locations for flowering time, leaf number and number of kernels per row. The inbred lines from the IDT and IND groups had shorter flowering time. The BSSS inbreds had significantly larger number of leaves, shorter ears, larger number of rows per ear, larger ear diameter

Table 4. Analysis of variance and comparison of means for eight phenotypic traits of six groups of maize inbred lines

\begin{tabular}{|c|c|c|c|c|c|c|c|c|}
\hline Group & $\begin{array}{c}\text { Days to } \\
\text { pollination }\end{array}$ & $\begin{array}{l}\text { Plant } \\
\text { height } \\
\mathrm{cm}\end{array}$ & $\begin{array}{c}\text { Leaf } \\
\text { number }\end{array}$ & $\begin{array}{c}\text { Ear length } \\
\mathrm{cm}\end{array}$ & $\begin{array}{c}\text { Ear } \\
\text { diameter } \\
\mathrm{cm}\end{array}$ & $\begin{array}{c}\text { Number } \\
\text { of rows } \\
\text { per ear }\end{array}$ & $\begin{array}{l}\text { Number of } \\
\text { kernels } \\
\text { per ear } \\
\text { row }\end{array}$ & $\begin{array}{c}\text { Yield } \\
\text { per plant } \\
\quad \mathrm{g}\end{array}$ \\
\hline IDT & $77.4 \mathrm{a}$ & $168.6 \mathrm{a}$ & $11.7 \mathrm{a}$ & $14.8 \mathrm{abc}$ & $3.8 \mathrm{a}$ & $13.7 \mathrm{a}$ & $23.5 \mathrm{a}$ & $96.9 \mathrm{a}$ \\
\hline IND & $78.7 \mathrm{a}$ & $174.8 \mathrm{ab}$ & $11.8 \mathrm{a}$ & $14.4 \mathrm{ab}$ & $3.7 \mathrm{a}$ & $13.9 \mathrm{a}$ & $24.2 \mathrm{ab}$ & $96.7 \mathrm{a}$ \\
\hline LSC & $82.1 \mathrm{~b}$ & $183.1 \mathrm{~b}$ & $12.4 \mathrm{~b}$ & $15.3 \mathrm{bc}$ & $3.7 \mathrm{a}$ & $12.9 \mathrm{~b}$ & $25.9 \mathrm{bc}$ & $96.8 \mathrm{a}$ \\
\hline $\mathrm{mLSC}$ & $82.4 \mathrm{~b}$ & $168.2 \mathrm{a}$ & $12.0 \mathrm{ab}$ & $15.8 \mathrm{c}$ & $3.7 \mathrm{a}$ & $13.9 \mathrm{a}$ & $27.4 \mathrm{c}$ & $104.1 \mathrm{a}$ \\
\hline BSSS & $81.5 \mathrm{~b}$ & $173.0 \mathrm{a}$ & $13.2 \mathrm{c}$ & $13.5 \mathrm{~d}$ & $4.1 \mathrm{~b}$ & $15.5 \mathrm{c}$ & $22.7 \mathrm{a}$ & $99.3 \mathrm{a}$ \\
\hline $\mathrm{mBSSS}$ & $81.4 \mathrm{~b}$ & $171.4 \mathrm{a}$ & $12.4 \mathrm{~b}$ & $13.9 \mathrm{ad}$ & $3.8 \mathrm{a}$ & $14.4 \mathrm{a}$ & $23.6 \mathrm{ab}$ & $103.2 \mathrm{a}$ \\
\hline Average & 80.6 & 173.2 & 12.3 & 14.6 & 3.8 & 14.1 & 24.5 & 99.5 \\
\hline 2011 & $77.8 \mathrm{a}$ & $188.2 \mathrm{a}$ & $12.3 \mathrm{a}$ & $15.4 \mathrm{a}$ & $3.9 \mathrm{a}$ & $14.4 \mathrm{a}$ & $27.0 \mathrm{a}$ & $117.6 \mathrm{a}$ \\
\hline 2012 & $83.5 \mathrm{~b}$ & $158.2 \mathrm{~b}$ & $12.2 \mathrm{a}$ & $13.8 \mathrm{~b}$ & $3.6 \mathrm{~b}$ & $13.8 \mathrm{~b}$ & $22.1 \mathrm{~b}$ & $81.3 \mathrm{~b}$ \\
\hline $\begin{array}{l}\text { Rimski } \\
\text { šančevi }\end{array}$ & $83.2 \mathrm{a}$ & $172.0 \mathrm{a}$ & $12.2 \mathrm{a}$ & $14.5 \mathrm{a}$ & $3.8 \mathrm{a}$ & $14.2 \mathrm{a}$ & $23.9 \mathrm{a}$ & $97.8 \mathrm{a}$ \\
\hline Srbobran & $78.0 \mathrm{~b}$ & $174.4 \mathrm{a}$ & $12.3 \mathrm{a}$ & $14.7 \mathrm{a}$ & $3.8 \mathrm{a}$ & $14.1 \mathrm{a}$ & $25.2 \mathrm{~b}$ & $101.1 \mathrm{a}$ \\
\hline Group (G) & $* *$ & $* *$ & $* *$ & $* *$ & $* *$ & $* *$ & $* *$ & $\mathrm{~ns}$ \\
\hline Year (Y) & $* *$ & $* *$ & ns & $* *$ & $* *$ & $* *$ & $* *$ & $* *$ \\
\hline Location (L) & $* *$ & ns & ns & ns & ns & ns & $*$ & ns \\
\hline $\mathrm{G} \times \mathrm{L}$ & ns & ns & ns & ns & ns & ns & ns & ns \\
\hline $\mathrm{G} \times \mathrm{Y}$ & ns & $\mathrm{ns}$ & ns & ns & ns & ns & ns & ns \\
\hline $\mathrm{Y} \times \mathrm{L}$ & $* *$ & ns & $*$ & ns & ns & ns & $*$ & ns \\
\hline $\mathrm{G} \times \mathrm{Y} \times \mathrm{L}$ & ns & ns & ns & ns & ns & ns & ns & ns \\
\hline
\end{tabular}

Note. IDT - Iodent, IND - independent, LSC - Lancaster Sure Crop, mLSC - mixed Lancaster Sure Crop, BSSS - Iowa Stiff Stalk Synthetic, mBSSS - mixed Iowa Stiff Stalk Synthetic; means in the same column with different superscript letters are significantly different; a-d $-P<0.05 ; *$ - significance at 0.01 probability level, * - significance at 0.05 probability level; ns - non significant.

and smaller number of kernels per row compared to the LSC, mLSC and most of the other groups (Table 4). The results show that all the groups had significant genetic variability and are suitable for further genetic analyses.

The relationship between inbred lines based on the phenotypic data was depicted on the biplot of PCA (Fig. 3). The first PC interpreted $32.1 \%$ of total variation, whereas the second PC accounted for $19.9 \%$, explaining together $52.0 \%$ of the total variation. Days to pollination, plant height and leaf number contributed most to the PC1, while ear length, number of rows per ear and number of kernels per row contributed most to the PC2. The PCA biplot showed positive correlations between yield, plant height and earliness (days to pollination), which form acute angles among each other. Similarly, positive correlations were found between ear length and number of kernels per ear row and between number of rows per ear and ear diameter. These two pairs of variables were negatively correlated, as the angles between their vectors were obtuse.

Most of the LSC inbred lines clustered on the upper part of the biplot, that is, with positive values of PC2, around the vectors for ear length and number of kernels per ear row (Fig. 3). Contrarily, the majority of BSSS lines were positioned on the lower part of the biplot, around vectors for number of rows, ear diameter and number of leaves. This depicted the main ear architecture characteristics of the two maize groups, in general, and was in keeping with the results obtained from ANOVA and means comparison tests. It also demonstrated the efficiency of PCA in differentiation between the BSSS and LSC pools, despite some overlap. However, PCA failed to distinctly separate the other four groups, indicating that the phenotypic traits chosen for 


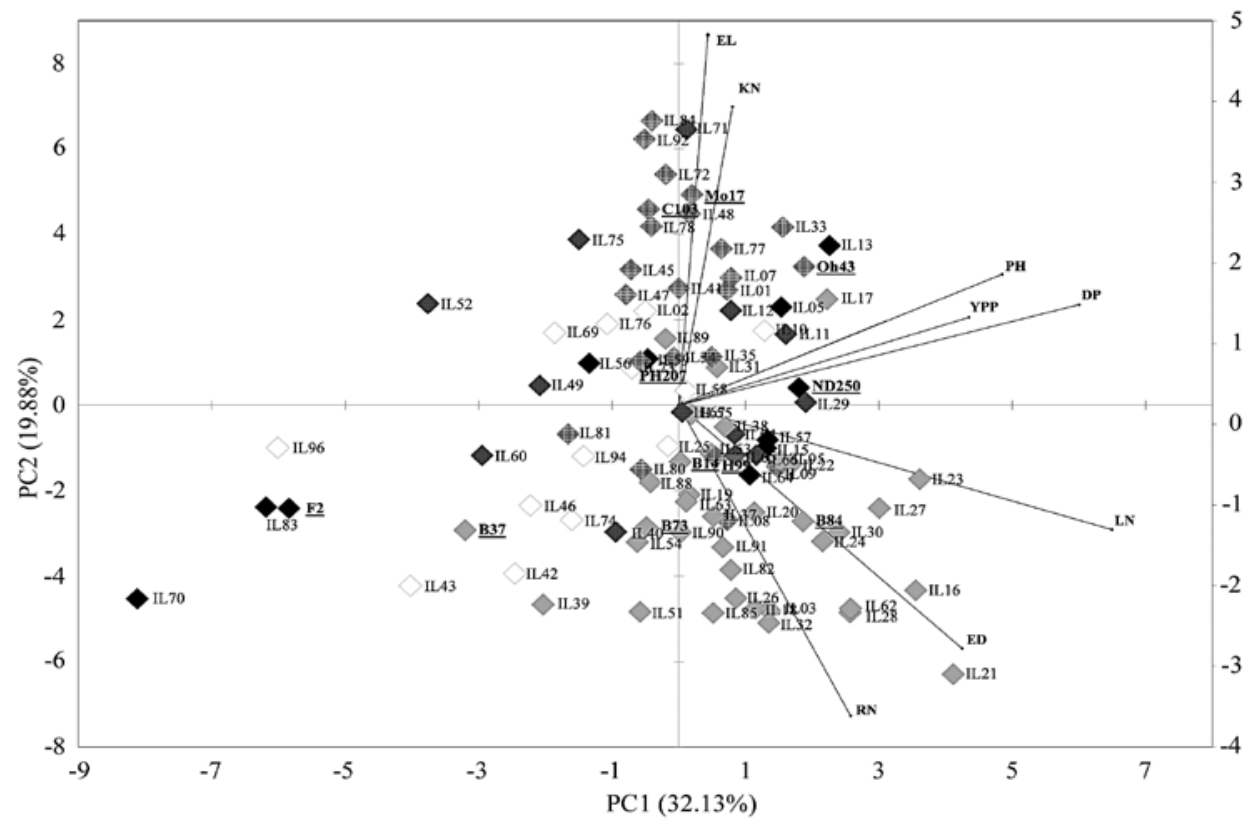

Note. Vertical lines - LSC inbred lines mixed with lines from other groups, horizontal lines - BSSS inbred lines mixed with those of other origins; grey - maize inbred lines belonging to BSSS pool, black - inbred lines from various independent sources, white - IDT lines; diamond - LSC inbred lines; EL - ear length, KN - number of kernels per ear row, PH - plant height, YPP - yield per plant, DP - days to pollination, LN - leaf number, ED - ear diameter, $\mathrm{RN}$ - number of rows per ear.

Figure 3. Principal component analysis of 96 maize inbred lines based of phenotypic data

the multivariate analysis were not discriminatory enough. Similar results were obtained by Babić et al. (2008), who used 30 traits from International Union for the Protection of New Varieties of Plants (UPOV) descriptor to classify 45 inbred lines with cluster and discriminant analyses. The authors clearly distinguished two clusters of inbreds, the one with complete or partial BSSS background and the other containing completely or partially LSC line, but the IDT and early French lines were includes in both clusters and did not group according to their heterotic group or origin.

In our study, the IDT and particularly IND inbreds were spread out along the vectors for plant height, yield and days to pollination, displaying large variation for these traits. The reason for such variation can be explained by heterogeneity of the IND group consisting of inbreds from rather different origin and by wider genetic bases of the IDT pool. Besides, the main selection criteria during inbred lines development, namely good combining abilities and the overall fitness, the driving force for creating divergent heterotic groups, were much better reflected on a molecular level. Molecular markers were more efficient in differentiating inbred lines according to their genetic backgrounds (Figs. 1 and 2) than the analysis based on phenotypic data. Babić et al. (2012) estimated values of correlations of morphological and molecular similarities for different maize inbred lines to range from 0.47 to 0.75 . The supremacy of PCoA and methods based on molecular markers in elucidating genetic relationship among maize inbred lines and reconstructing pedigrees were also reported in previous studies (Nelson et al., 2008; Van Inghelandt et al., 2010; Lorenz, Hoegemeyer, 2013). The information obtained from molecular analyses may facilitate breeders to better characterise and classify genetic resources in heterotic groups and exploit heterotic patterns for superior hybrid development.

\section{Conclusions}

1. Microsatellite-based cluster analysis and principal coordinate analysis (PCoA) assigned 96 inbred lines to six clusters, namely, Iowa Stiff Stalk Synthetic (BSSS), Lancaster Sure Crop (LSC), Iodent (IDT) heterotic group, a cluster with unrelated independent inbreds and two clusters of miscellaneous germplasm crossed with inbreds of BSSS and Lancaster origin.

2. The microsatellites revealed considerable level of genetic diversity of the investigated groups of maize inbred lines, reflecting the importance and prevalence of selection and improvement of the BSSS and Lancaster pools during maize breeding.

3. The investigated inbred lines demonstrated sufficient variation in most of the analysed phenotypic traits, which enables their further use for various genetic studies, such as association mapping for traits of interest.

4. Marker-based methods were more efficient in assigning inbred lines to their corresponding heterotic groups and elucidating their genetic relationships than the analysis based on phenotypic data. The molecular characterisation and classification of genetic resources may assist hybrid breeding by efficient exploitation of heterotic patterns.

\section{Acknowledgments}

This research is supported by the Ministry of Education, Science and Technological Development of the Republic of Serbia (project TR-31073).

Received 29082016

Accepted 30122016 


\section{References}

Babić V., Babić M., Filipović M., Delić N., Anđelković V. 2008. Phenotypic characterization and relatedness of maize inbred lines. Genetika. 40 (3): 227-236 https://doi.org/10.2298/GENSR0803227B

Babić M., Babić V., Prodanović S., Filipović M., Anđelković V. 2012. Comparison of morphological and molecular genetic distances of maize inbreds. Genetika. 44 (1): 119-128 https://doi.org/10.2298/GENSR1201119B

Cooper M., van Eeuwijk F. A., Hammer G. L., Podlich D. W., Messina C. 2009. Modeling QTL for complex traits: detection and context for plant breeding. Current Opinion in Plant Biology. 12 (2): 231-240 https://doi.org/10.1016/j.pbi.2009.01.006

El-Kassaby Y. A., Cappa E. P., Liewlaksaneeyanawin C., Klapšte J., Lstibrek M. 2011. Breeding without breeding: is a complete pedigree necessary for efficient breeding? PLoS One. 6 (10): e25737 https://doi.org/10.1371/journal.pone.0025737

Guo M., Rupe M.A., Wei J., Winkler C., Goncalves-Butruille M., Weers B. P., Cerwick S. F., Dieter J. A., Duncan K. E., Howard R. J., Hou Z. 2014. Maize ARGOS1 (ZAR1) transgenic alleles increase hybrid maize yield. Journal of Experimental Botany. 65 (1): 249-260 https://doi.org/10.1093/jxb/ert370

Hadi G. 2006. Maize varieties in Eastern Central Europe in the first decades of the $20^{\text {th }}$ century. Acta Agronomica Hungarica. 54 (1): 69-82 https://doi.org/10.1556/AAgr.54.2006.1.7

Holland J. B. 2007. Genetic architecture of complex traits in plants. Current Opinion in Plant Biology. 10 (2): 156-161 https://doi.org/10.1016/j.pbi.2007.01.003

Huson D. H., Richter D. C., Rausch C., Dezulian T., Franz M., Rupp R. 2007. Dendroscope: an interactive viewer for large phylogenetic trees. BMC Bioinformatics, 8: 460 https://doi.org/10.1186/1471-2105-8-460

Jiao Y., Zhao H., Ren L., Song W., Zeng B., Guo J., Wang B., Liu Z., Chen J., Li W., Zhang M. 2012. Genome-wide genetic changes during modern breeding of maize. Nature Genetics. 44 (7): $812-815$ https://doi.org/10.1038/ng.2312

Jones E. S., Sullivan H., Bhattramakki D., Smith J. S. 2007. A comparison of simple sequence repeat and single nucleotide polymorphism marker technologies for the genotypic analysis of maize (Zea mays L.). Theoretical and Applied Genetics. 115 (3): 361-371 https://doi.org/10.1007/s00122-007-0570-9

Liu H., Wang X., Warburton M. L., Wen W., Jin M., Deng M., Liu J., Tong H., Pan Q., Yang X., Yan J. 2015. Genomic, transcriptomic, and phenomic variation reveals the complex adaptation of modern maize breeding. Molecular Plant. 8 (6): $871-884$ https://doi.org/10.1016/j.molp.2015.01.016

Lorenz A., Hoegemeyer T. 2013. The phylogenetic relationships of US maize germplasm. Nature Genetics, 45 (8): 844-845 https://doi.org/10.1038/ng.2697

Mitrović B., Stojaković M., Zorić M., Stanisavljević D., Bekavac G., Nastasić A., Mladenov V. 2016. Genetic gains in grain yield, morphological traits and yield stability of middle-late maize hybrids released in Serbia between 1978 and 2011. Euphvtica https://doi.org/10.1007/s10681-016-1739-6

Nelson P. T., Coles N. D., Holland J. B., Bubeck D. M., Smith S., Goodman M. M. 2008. Molecular characterization of maize inbreds with expired US plant variety protection. Crop Science. 48 (5): 1673-1685 https://doi.org/10.2135/cropsci2008.02.0092

Olmos S. E., Delucchi C., Ravera M., Negri M. E., Mandolino C., Eyherabide G. H. 2014. Genetic relatedness and population structure within the public Argentinean collection of maize inbred lines. Maydica, 59 (1): 16-31

Peakall R., Smouse P. E. 2012. GenAlEx 6.5: genetic analysis in Excel. Population genetic software for teaching and research - an update. Bioinformatics. 28 (19): 2537-2539 https://doi.org/10.1093/bioinformatics/bts460
Romay M. C., Millard M. J., Glaubitz J. C., Peiffer J. A., Swarts K. L., Casstevens T. M., Elshire R. J., Acharya C. B., Mitchell S. E., Flint-Garcia S. A., McMullen M. D. 2013. Comprehensive genotyping of the USA national maize inbred seed bank. Genome Biology. 14 (6): R55 https://doi.org/10.1186/gb-2013-14-6-r55

Schaefer C. M., Bernardo R. 2013. Population structure and single nucleotide polymorphism diversity of historical Minnesota maize inbreds. Crop Science. 53 (4): 1529-1536 https://doi.org/10.2135/cropsci2012.11.0632

Semagn K., Magorokosho C., Vivek B. S., Makumbi D., Beyene Y., Mugo S., Prasanna B. M., Warburton M. L. 2012. Molecular characterization of diverse CIMMYT maize inbred lines from eastern and southern Africa using single nucleotide polymorphic markers. BMC Genomics. 13 (1): 113 https://doi.org/10.1186/1471-2164-13-113

Smith S. D., Murray S. C., Heffner E. 2015. Molecular analysis of genetic diversity in a Texas maize (Zea mays L.) breeding program. Maydica, 60: M20

Stojaković M., Mitrović B., Zorić M., Ivanović M., Stanisavljević D., Nastasić A., Dodig D. 2015. Grouping pattern of maize test locations and its impact on hybrid zoning. Euphvtica. 204 (2): 419-431 https://doi.org/10.1007/s10681-015-1358-7

Technow F., Schrag T. A., Schipprack W., Melchinger A. E. 2014. Identification of key ancestors of modern germplasm in a breeding program of maize. Theoretical and Applied Genetics. 127 (12): 2545-2553 https://doi.org/10.1007/s00122-014-2396-6

van Heerwaarden J., Hufford M. B., Ross-Ibarra J. 2012. Historical genomics of North American maize. Proceedings of the National Academy of Sciences, 109 (31): $12420-12425$ https://doi.org/10.1073/pnas.1209275109

Van Inghelandt D., Melchinger A. E., Lebreton C., Stich B. 2010. Population structure and genetic diversity in a commercial maize breeding program assessed with SSR and SNP markers. Theoretical and Applied Genetics, 120 (7): 1289-1299 https://doi.org/10.1007/s00122-009-1256-2

Wu X., Li Y., Li X., Li C., Shi Y., Song Y., Zheng Z., Li Y., Wang T. 2015. Analysis of genetic differentiation and genomic variation to reveal potential regions of importance during maize improvement. BMC Plant Biology, 15 (1): 256 https://doi.org/10.1186/s12870-015-0646-7

Wu Y., San Vicente F., Huang K., Dhliwayo T., Costich D. E., Semagn K., Sudha N., Olsen M., Prasanna B. M., Zhang X., Babu R. 2016. Molecular characterization of CIMMYT maize inbred lines with genotyping-by-sequencing SNPs. Theoretical and Applied Genetics. 129 (4): 753-765 https://doi.org/10.1007/s00122-016-2664-8

Yan J., Shah T., Warburton M. L., BucklerE. S., McMullen M. D., Crouch J. 2009. Genetic characterization and linkage disequilibrium estimation of a global maize collection using SNP markers. PLoS One. 4: e8451 https://doi.org/10.1371/journal.pone.0008451

Yang X., Yan J., Shah T., Warburton M. L., Li Q., Li L., Gao Y., Chai Y., Fu Z., Zhou Y., Xu S., Bai G., Meng Y., Zheng Y., Li J. 2010. Genetic analysis and characterization of a new maize association mapping panel for quantitative trait loci dissection. Theoretical and Applied Genetics, $121(3): 417-431$ https://doi.org/10.1007/s00122-010-1320-y

Yang X., Xu Y., Shah T., Li H., Han Z., Li J., Yan J. 2011. Comparison of SSRs and SNPs in assessment of genetic relatedness in maize. Genetica. 139 (8): 1045-1054 https://doi.org/10.1007/s10709-011-9606-9

Zheng D. H., Van K., Lee S. H. 2008. Molecular diversity and relationships among elite maize inbreds from US and CIMMYT populations and current heterotic groups in China. Hereditas, 145 (4): 182-193 https://doi.org/10.1111/j.0018-0661.2008.02048.x 
ISSN 1392-3196 / e-ISSN 2335-8947

Zemdirbyste-Agriculture, vol. 104, No. 1 (2017), p. 31-40

DOI 10.13080/z-a.2017.104.005

\title{
Paprastojo kukurūzo inbredinių linijų molekulinis ir fenotipinis įvertinimas Pietryčių Europoje
}

\author{
S. Mikić1, A. Kondić-Špika ${ }^{1}$, L. Brbaklić², D. Stanisavljević ${ }^{1}$, M. Ćeran ${ }^{1}$, D. Trkulja ${ }^{1}$, \\ B. Mitrović ${ }^{1}$
}

${ }^{1}$ Serbijos lauko augalų ir daržovių institutas

${ }^{2}$ Biogranum tyrimų ir plètros centras, Serbija

\section{Santrauka}

Paprastajam kukurūzui (Zea mays L.) būdinga genetinè ịvairovè, istoriškai susiformavusi nuo jo introdukavimo iš kilmès centro Meksikoje ị kitas pasaulio vietas, ir prisitaikymas prie ịvairių auginimo sąlygų. Nepaisant šios ịvairovės, vykdant paprastojo kukurūzo selekciją ir kuriant hibridus panaudojama tik maža dalis turimos genetinės medžiagos. Siekiant selekcinių kolekcijų ịvairovę praplèsti naujais genotipais kaip tinkamų požymių šaltiniu, reikia ją apibūdinti ir suklasifikuoti ị heterozines grupes.

Tyrimo tikslas - ivvertinti Serbijos lauko augalų ir daržovių instituto turimos paprastojo kukurūzo selekcinès medžiagos genetinę ịvairovę, taip pat ir anksčiau neapibūdintas inbredines linijas, žinomos kilmès elitines linijas ir istoriškai svarbias inbredines linijas. Mikrosatelitų metodu atlikus klasterinę ir principinių koordinačių analizes 96 inbredinès linijos buvo suskirstytos ị šešias grupes: Iowa Stiff Stalk Synthetic (BSSS), Lancaster Sure Crop (LSC), Iodent (IDT) heterozinè grupè, negiminingų inbredų grupé ir dvi grupės genetinès medžiagos, sukryžmintos su BSSS ir Lancaster inbredais. I grupes skirstyta pagal mikrosatelitus umc1035, bnlg666, dupssr23, umc1083 ir dupssr 10. Molekulinès ịvairovès didžiausios parametrų vertès nustatytos BSSS grupejje, po to Lancaster ir kitose grupése. Dispersinè analizè parodė, kad beveik visi požymiai reikšmingai varijavo tarp grupių ir metų. Tirtosios linijos pasižymėjo pakankama daugelio analizuotų fenotipinių požymių variacija ir pasirodè tinkamos tolesniems genetiniams tyrimams. Principinė komponentinè analizè pagal agronominius požymius inbredines linijas atskyrė nuo BSSS ir Lancaster genetinių grupių, tačiau taikant šią analizę nepavyko identifikuoti kitu grupių. Genetinių išteklių apibūdinimas ir klasifikavimas pagal mikrosatelitinius žymeklius gali padèti kuriant hibridus ir veiksmingai panaudojant heterozinius modelius.

Reikšminiai žodžiai: heterozinès grupès, inbredai, mikrosatelitai, paprastos pasikartojančios sekos, Zea mays. 